
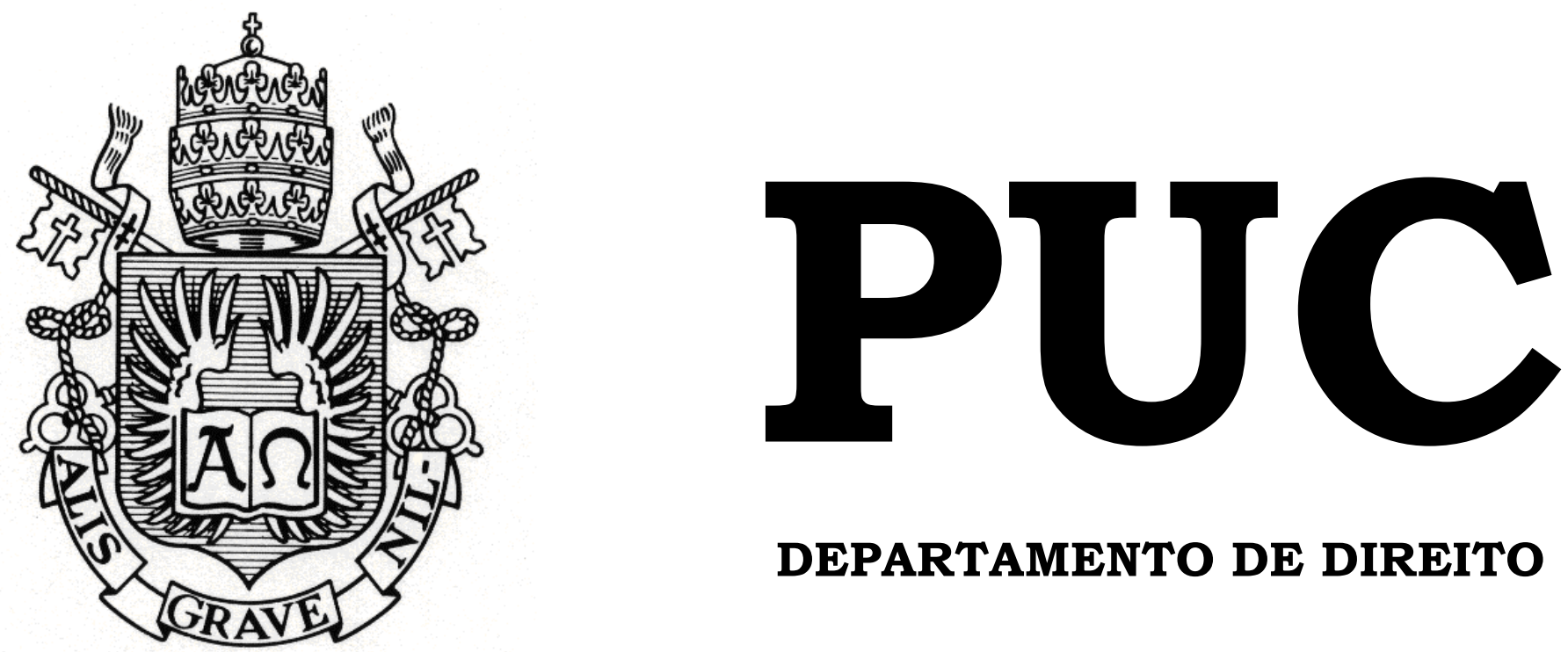

DEPARTAMENTO DE DIREITO

\title{
O CASTIGO NA RESSOCIALIZAÇÃO DOS CONDENADOS
}

por

LUCAS CALDAS LAFAYETTE STOCKLER

ORIENTADOR: CARLOS RAYMUNDO CARDOSO

2016.2

PONTIFÍCIA UNIVERSIDADE CATÓLICA DO RIO DE JANEIRO

RUA MARQUÊS DE SÃO VICENTE, 225 - CEP 22453-900

RIO DE JANEIRO - BRASIL 


\title{
O CASTIGO NA RESSOCIALIZAÇÃO DOS CONDENADOS
}

\author{
por \\ LUCAS CALDAS LAFAYETTE SOTCKLER
}

Monografia

apresentada

ao

Departamento de Direito da Pontificia Universidade Católica do Rio de Janeiro (PUC-Rio) para a obtenção do Título de Bacharel em Direito.

Orientador: Carlos Raymundo Cardoso 


\section{Agradecimentos}

A monografia - principalmente a monografia de um aluno de primeira graduação - sempre é um momento simbólico. É o fechamento de um ciclo muito maior que uma mera faculdade, é o fim de todo de toda uma formação profissional iniciada e sonhada desde os primeiros dias de maternal. Mais do que um bar mitzvah ou um baile de debutantes, ela marca a verdadeira e triunfal entrada do jovem no mundo adulto.

Como em todo grande ciclo, a jornada jamais seria concluída sem a ajuda de outros. No meu caso, falamos principalmente de minha família. Afinal, o encargo de ter me moldado no individuo que sou, com as convicções que tenho, vem principalmente deles que, em todo momento, me apoiaram e incentivaram.

Quero agradecer ao meu caríssimo orientador, o Professor Carlos Raymundo Cardoso, que aceitou guiar-me neste trabalho, bem como foi fundamental na construção de meu pensamento crítico no tema.

Gostaria, também, de agradecer especialmente aos professores Breno Melaragno e André Perecmanis que, em suas aulas de Direito Penal, deramme as melhores bases de conhecimento na área que eu jamais poderia desejar.

Outros agradecimentos - não menos importantes - vão aos meus amigos, da faculdade e de outras aventuras, que compartilharam comigo as experiências que tornaram aquele que sou hoje.

Por fim, agradeço a todos os professores que contribuíram com a minha formação, pessoal e acadêmica. Do Espaço Total ao pH e então à PUC-Rio e à vida, os frutos de meus estudos eu devo à vocês. 


\section{Resumo}

O presente trabalho busca debater a função do Castigo na ressocialização dos condenados. Para isso, observar-se-á, de forma crítica, o sistema penal atual, o desempenho do Castigo e da ressocialização nas penitenciárias, as raízes de sua demanda histórica por parte da sociedade e as falhas em sua aplicação. Por fim, algumas alternativas que reimaginam ambos os institutos serão colocadas.

Palavras-chave: Castigo, Pena, Ressocialização, Penitenciária, Sistema Penal. 


\section{Sumário}

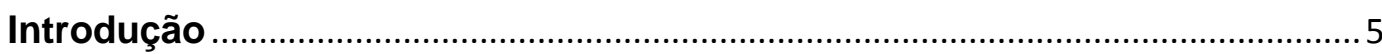

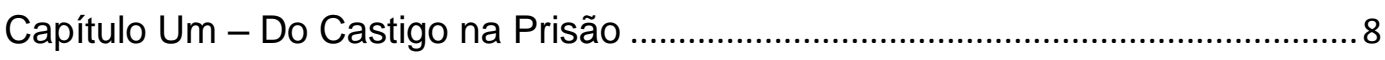

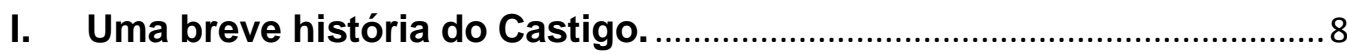

II. A realidade do discurso ressocializador. .............................................10

III. A inefetividade da domesticação. ......................................................... 14

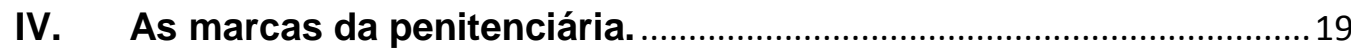

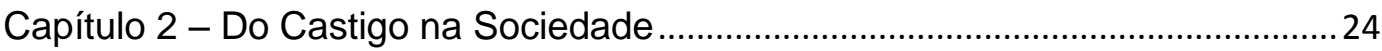

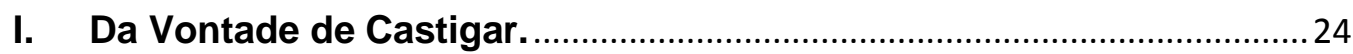

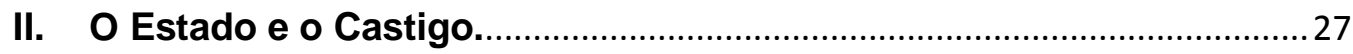

III. A Deslegitimação da Penitenciária como Castigo. ...............................30

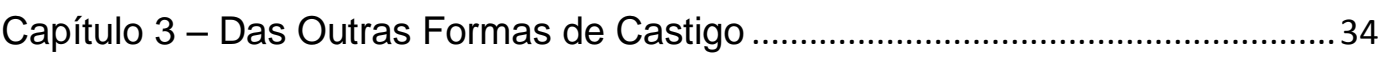

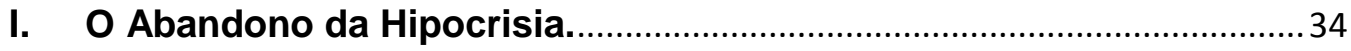

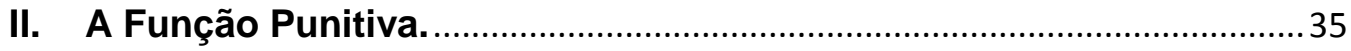

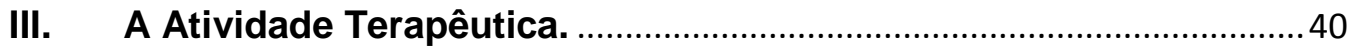

IV. O Direito Penal Mínimo e o Abolicionismo Penal................................43

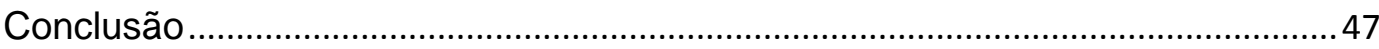

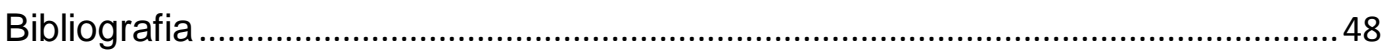


"Há uma passagem que eu memorizei, que parece oportuna para esta situação: Ezequiel 25:17. "O caminho do justo está cercado por todos os lados pelas iniquidades dos egoístas e pela tirania dos perversos. Bendito é aquele que, em nome da caridade e da boa vontade, pastoreia os fracos pelo vale das trevas, pois ele é verdadeiramente o protetor de seus irmãos e o salvador dos filhos perdidos. E Eu atacarei com grande vingança e raiva furiosa aqueles que tentam envenenar e destruir meus irmãos. E você saberá: meu nome é o Senhor quando minha vingança cair sobre ti!"."

- Personagem de Samuel L. Jackson, antes de alvejar um dos personagens secundários do filme Pulp Fiction.

\section{Introdução}

"Na cadeia ele vai ver o que é bom"; "esse ai merece ficar preso pelo resto da vida"; "direitos humanos para humanos direitos"; "tem que bater mesmo"; "bandido bom é bandido morto"; "penitência"; "ele tem que pagar pelo que fez". Estes e muitos outros axiomas são tidos, no imaginário popular, como as duras verdades negligenciadas pelo poder público. São frases constantemente repetidas e há muito internalizadas por alguns, mas cujos reais significados são pouco compreendidos. O que esses enunciam é, em síntese, o caráter essencial do Castigo na ressocialização dos criminosos.

O objetivo do presente trabalho é justamente confrontar tal assertiva.

Convém, desde já, definir o que será entendido como Castigo (com letra maiúscula), neste trabalho. O conceito de castigo (com letra minúscula) se confunde com o conceito de pena, uma vez que esta significa a infligir um mal a outrem, em razão de uma ação ou omissão contrária à norma expedida por autoridade competente. $\mathrm{O}$ conceito de Castigo, por sua vez, é mais fluido que esse. Trata-se do caráter essencialmente punitivo da pena aplicado de forma eficaz; apenas daquela vil parcela da pena que a sociedade livre acredita ser devida ao criminoso, a única capaz de aplacar sua sede de justiça e de impedir novos delitos, aquela cuja ausência se torna sinônimo de impunidade. 
Aos olhos de nossos nobres e idôneos cidadãos, somente as penas fundamentalmente sofridas são aptas a remediar os injustos que lhes foram causados, ao mesmo tempo em que controlam a massa criminosa. A despeito de existirem em todas as épocas formas menos gravosas ou alternativas de pena, a realidade sempre fora a mesma: a sociedade somente acredita que a justiça tenha sido feita quando a pena infligir sofrimento só quando o Castigo era efetivo. A história comprova. O Castigo já fora realizado com o ostracismo, com as disputas no Coliseu, com os ordálios, os suplícios e com a sempre presente pena de morte. E, agora é a vez do encarceramento em regime fechado nas penitenciárias.

Hoje, com o avanço das teorias da pena, o Castigo passou a dividir espaço com ideias de ressocialização e a sociedade se dividiu entre aqueles que advogam pela prevalência de um ou outro no ambiente carcerário. De um lado, acredita-se que o Castigo é essencial para tutelar o condenado a não mais cometer crimes; de outro, defende-se que a imposição forçada de uma rígida disciplina tem mais males que benefícios, sendo necessário dar espaço para o condenado desenvolver suas faculdades e regenerar-se como individuo.

Ocorre que, diferentemente das argumentações usuais, exporemos como nenhuma das duas teses é a ideal. O melhor caminho é, para o orgulho de Roxin, a síntese dos dois. O Castigo não apenas é prejudicial ao condenado na forma que ele se manifesta nas prisões, como também é inconciliável com a ressocialização; e essa é, enquanto isso, inalcançável dentro do sistema penitenciário. Dessa forma, deve-se reimaginar o sistema penitenciário, quiçá toda a execução da pena, para a aplicação de um Castigo que esteja de acordo com as noções retributivas e preventivas da pena e que não prejudique também o reformulado instituto da ressocialização. 
Para isso, analisaremos, em uma primeira etapa, o mito da Ressocialização, debruçando-nos sobre o sistema penitenciário e seu funcionamento. Restará exposto como as finalidades retributivas e preventivas da pena são inconciliáveis com a ressocialização e sempre prevalecem a ela. Simultaneamente, ainda no campo da teoria, vamos tratar dos efeitos malignos do Castigo e de como esse opera a chamada prisionização nos condenados, prejudicando até mesmo seu tempo póscumprimento da pena.

Na próxima etapa, realizaremos uma análise da sociedade, de modo a expor sua relação com o Castigo. Através de uma análise psicológica e filosófica do instituto, será transparente que a sociedade exige a aplicação dele, razão pela qual prosseguiremos ao posicionamento que o Estado deve assumir para com o Castigo. Enfim, culminaremos nas razões da insatisfação e na ineficiência das penitenciárias como meios de aplicação do Castigo.

$\mathrm{Na}$ terceira e última etapa, concluiremos esse trabalho com algumas propostas de como lidar com toda a problemática exposta. Serão levantadas alternativas para a aplicação do Castigo, bem como para a aplicação da ressocialização. Por fim, colocaremos duas correntes ideológicas que podem nortear a mudança e, possivelmente, salvar nosso país deste complicado problema que é a questão penitenciária. 


\section{Capítulo Um - Do Castigo na Prisão}

\section{Uma breve história do Castigo.}

Não é a intenção deste trabalho fazer as vezes de um historiador. Entretanto, para que possamos compreender a inexorável presença do Castigo no inconsciente popular, é preciso, como normalmente o é, realizar um apanhado geral do histórico da pena até nossa situação atual.

Tínhamos, até meados do século XIX, uma espécie de pena preponderante: o suplício. Cadafalsos, carrascos, guilhotinas, esquartejamentos, fogueiras e rodas, açoitamentos todos esses e outros elementos foram utilizados, através dos anos, para executar esta pena, cujo objetivo era infligir uma quantidade de sofrimento suficiente no corpo do supliciado para expurgar-lhe o crime cometido e reestabelecer a ordem perdida.

O suplício é ostentação de poder, um grande Castigo espetacularizado; ou, como colocou Foucault: "O suplício repousa na arte quantitativa do sofrimento" ${ }^{1}$. Fundamenta-se não apenas no direito da vítima de ver seu dano reparado, mas principalmente no direito do rei de castigar aquele que menosprezou suas leis e atacou sua autoridade, no triunfo do rei sobre seus adversários, na restauração da ordem. "Em toda infração há um crimen majestatis, e no menor dos criminosos um pequeno regicida em potencial" ${ }^{2}$.

Trata-se de penas atrozes que não apenas retribuem o injusto causado como, em seu excesso, reafirmam o poder do rei perante seus súditos. Esses são convidados pelo soberano como espectadores de um show. Exercem, simultaneamente, os papéis de testemunhas do horror que aguardava aqueles que contrariavam a autoridade real e de fiscais da punição - vez que

\footnotetext{
${ }^{1}$ FOUCAULT, Michel. Vigiar e Punir: Nascimento da Prisão. 33a Edição. Petrópolis: Editora Vozes, 2007. p. 31.

${ }^{2}$ Ibid. p. 46.
} 
estavam lá também para garantir que o soberano não fraquejasse e desse o Castigo ao supliciado.

Ocorre que, a partir do final do século XVIII até meados do século XIX, o suplício entrou em seu ocaso. Não é nenhuma surpresa quando constatamos que, no decorrer dos últimos séculos, houve um nítido afrouxamento da severidade penal. Muitas razões poderiam ser apontadas para tanto, desde a pressão iluminista por uma humanização das penas, até a percepção de que o suplício representava para o Estado uma faca de dois gumes $^{3}$. Fato é que, por toda Europa, a festa da punição física começou a desaparecer; a sociedade mudou sua concepção de Castigo e o suplício tornou-se excessivo aos olhos dos comuns. "O castigo passou de uma arte das sensações insuportáveis a uma economia dos direitos suspensos " 4.

Ocorre uma diminuição na intensidade das punições e, mais importante, uma mudança em seu objetivo ${ }^{5}$. Não mais se exerce a punição sobre o corpo supliciado, mas sim sobre a alma do criminoso. Entende-se que a justiça penal não deve consistir na vingança do soberano, mas sim na justa punição do criminoso - e só seria justa a punição que respeitasse sua dignidade como "homem". Para salvaguardar a humanidade descoberta no coração dos condenados, assume-se a difícil tarefa de corrigi-los e transformá-los em indivíduos retos, cidadãos exemplares de nossa sociedade, corpos dóceis ${ }^{6}$.

Reimagina-se, então, as prisões. Essas sempre existiram e sempre foram utilizadas quando era necessário separar indivíduos do corpo social e contê-los em um só lugar por qualquer que fosse a razão. Ou seja, a prisão existia, até então, como forma de garantir a aplicação do Castigo, como

\footnotetext{
${ }^{3}$ Acidentalmente, o suplício demonstrava a fragilidade da autoridade real. Ele içava ao heroísmo o supliciado que encarava sua pena sem medo, deixava exposto o povo àqueles que desafiavam o rei e expunham o excesso na punição que cada vez mais parecia injusto aos olhos do povo. A vingança do soberano acabava por ser pretexto para a revanche do povo.

${ }^{4}$ FOUCAULT, Michel. Vigiar e Punir. p. 14.

${ }^{5}$ Ibid. p. 18.

6 "A disciplina fabrica assim corpos submissos e exercitados, corpos "dóceis"." - FOUCAULT, Michel. Vigiar e Punir. p. 119.
} 
uma cautelar a ser usada para impedir fugas e garantir a obtenção da verdade. Eram os calabouços e as masmorras onde os processados eram interrogados e torturados e onde aguardavam para descobrir e receber seu suplício.

Esse instituto, que sempre estivera ali, à disposição, cai como uma luva no novo objetivo do sistema penal. Era a pena perfeita, uma vez que atingia as pessoas em seu bem mais valioso, a liberdade, ao mesmo tempo em que às remodelava em um novo e inofensivo cidadão. Estabeleceu-se, então, em prol da ressocialização do condenado, sua completa vigilância; pois essa significava sua total perda de privacidade e, por conseguinte, da sua liberdade de agir e pensar por si mesmo - ou seja, significava controle absoluto.

Surgem, enfim, a prisão-instituição, a penitenciária, e dá-se inicio à sociedade disciplinar.

\section{A realidade do discurso ressocializador.}

O discurso ressocializador prega a regeneração do criminoso em um cidadão idôneo através de uma ação pedagógica. Valendo-se de recursos como o trabalho intra e extramuros, bem como com a atividade de médicos e psicólogos, a pena adota o objetivo de iluminar o condenado quanto aos erros de seus caminhos e conduzi-lo a um percurso mais virtuoso. Toda essa atividade é realizada mediante coerção de um sistema penitenciário que, além de cumprir tal função ressocializadora, também é responsável por punir e intimidar o condenado, isto é, cumprir com a dimensão punitiva da pena - dar o Castigo.

Eis o primeiro ponto de conflito que encontramos no discurso contemporâneo. Como pode um homem ser ressocializado e punido e intimidado ao mesmo tempo? Nas palavras de Bernard Shaw: "Para punir 
um homem retributivamente é preciso injuriá-lo. Para reformá-lo, é preciso melhorá-lo. E os homens não são melhoráveis através de injúrias" 7.

O Castigo é o fazer sofrer e a intimidação decorrente de tal sofrimento, é a resposta do Estado à violência cometida contra suas leis, é o pedido de justiça da sociedade. Por outro lado, a ação pedagógica é absolutamente dependente da cooperação e do entendimento de seu paciente - ficando extremamente difícil de sustentar o discurso da penitenciária ressocializadora.

Tal contradição foi apontada já por diversos teóricos, dentre eles Johan Galtung, que listou oito incompatibilidades entre a função punitiva da pena (na qual o Castigo se enquadra, a depender de sua eficácia) e a atividade terapêutica ${ }^{8}$ :

\begin{tabular}{|c|c|}
\hline Função Punitiva & Atividade Terapêutica \\
\hline Observa uma orientação punitiva & $\begin{array}{l}1 . \quad \text { Observa } \\
\text { tratamento }\end{array}$ \\
\hline $\begin{array}{l}\text { 2. Tem uma ideologia concernente a } \\
\text { prisões e prisioneiros no sentido de que } \\
\text { circunstâncias externas, exculpatórias, são } \\
\text { somente circunstâncias necessárias, não } \\
\text { causas suficientes de atos criminosos, em } \\
\text { razão do fato de serem tomados como } \\
\text { certos os princípios do livre arbítrio } \\
\text { individual e da auto-causação. }\end{array}$ & $\begin{array}{l}\text { 2. Tem uma ideologia concernente a } \\
\text { prisões e presos no sentido de que as } \\
\text { circunstâncias externas, exculpatórias } \\
\text { determinantes sociais, mentais, biológicas } \\
\text { e físicas são vistas como causas tanto } \\
\text { necessárias como suficientes do crime. }\end{array}$ \\
\hline $\begin{array}{l}\text { 3. Pinta a prisão, para a sociedade, em } \\
\text { termos negativos; assim, ela funciona como } \\
\text { uma intimidação coletiva e como uma }\end{array}$ & $\begin{array}{l}\text { 3. Apresenta a prisão, para a sociedade, } \\
\text { como um símbolo neutro ou positivo. }\end{array}$ \\
\hline
\end{tabular}

\footnotetext{
${ }^{7}$ CROSS, Rupert. Punishment prison and the public. $2^{\mathrm{a}}$ Edição. Londres: Stevens and Sons, 1971. p. 47. Apud THOMPSON, Augusto. A Questão Penitenciária. 5a Edição. Rio de Janeiro: Editora Forense, 2000. p. 5.

${ }^{8}$ KNUDTEN, Richard D.. Crime in a Complex Society. Illinois: Dorsey Press, 1970. p. 612. Apud THOMPSON, Augusto. A Questão Penitenciária. p. 6 e 7.
} 


\begin{tabular}{|c|c|}
\hline referência geral de sanções negativas. & \\
\hline $\begin{array}{l}\text { 4. Força o recolhimento do interno à } \\
\text { prisão, contra a vontade. }\end{array}$ & $\begin{array}{l}\text { 4. Espera que o interno adote uma atitude } \\
\text { de boa vontade para submeter-se à terapia. }\end{array}$ \\
\hline $\begin{array}{l}5 . \text { Intencionalmente (e com o } \\
\text { conhecimento do interno de que a ação é } \\
\text { intencional) infligi-lhe sofrimentos ou } \\
\text { priva-o de valores positivos, durante sua } \\
\text { estada na prisão. }\end{array}$ & $\begin{array}{l}\text { 5. Espera que o interno acredite que o que } \\
\text { se faz o é para seu próprio bem e como } \\
\text { cooperação ao seu tratamento. }\end{array}$ \\
\hline $\begin{array}{l}\text { lnstitucionaliza } \\
\text { secundárias entre os internos es es } \\
\text { funcionários, num esforço para assegurar } \\
\text { igualdade no tratamento e para prevenir a } \\
\text { formação de personalidades que podem pôr } \\
\text { em perigo a eficiência da operativa, em } \\
\text { dadas emergências. }\end{array}$ & $\begin{array}{l}\text { 6. Institucionaliza relações primárias entre } \\
\text { os internos e os funcionários, num esforço } \\
\text { para assegurar ou facilitar uma } \\
\text { transferência de valores destes para } \\
\text { aqueles. }\end{array}$ \\
\hline $\begin{array}{l}\text { 7. Treina o pessoal para se orientar } \\
\text { somente por variáveis simples, consensuais } \\
\text { e altamente visíveis, como idade, crime } \\
\text { cometido, carreira criminal e sentença. }\end{array}$ & $\begin{array}{l}\text { 7. Treina o pessoal para se orientar por } \\
\text { características sutis, dissensuais e latentes } \\
\text { dos internos. }\end{array}$ \\
\hline $\begin{array}{l}8 . \quad \text { Solta o interno depois de } \\
\text { período de tempo que está fixado } \\
\text { função, principalmente, de } \\
\text { comportamento seu } \\
\text { institucionalizado. }\end{array}$ & $\begin{array}{l}\text { 8. Solta o interno depois de um período de } \\
\text { tempo que está fixado em função, } \\
\text { principalmente, de seu comportamento } \\
\text { depois de estar institucionalizado. }\end{array}$ \\
\hline
\end{tabular}

Em seu âmago, a atividade terapêutica é diametralmente oposta da função punitiva, sendo impossível realiza-las de forma eficiente ao mesmo tempo. Cabe, então, à administração penitenciária optar pelo sucesso de uma função e consequente falha de outra.

Ocorre que tal "escolha" não passa de uma ilusão, vez que a sociedade livre já a tomara muito antes da administração penitenciária tê-la examinado. 
Para a efetiva realização de qualquer uma das funções da pena punição, intimidação e ressocialização - é necessário que a administração penitenciária garanta a segurança e a disciplina dentro do ambiente carcerário. Apenas assim a penitenciária poderia evitar fugas, crimes e garantir que o detento estaria sim sujeito à suas medidas, sejam elas punitivas ou terapêuticas. Pode-se entender que a segurança e a disciplina são meios necessários para a realização de qualquer dos fins da pena.

Entretanto, "tal é o grau de importância emprestado a esses meios (...) que a sociedade os eleva a uma posição de prevalência, relativamente aos próprios fins" 9 .

Os controles informais da sociedade livre se preocupam em fiscalizar, quase que exclusivamente, a satisfação dos meios, pouco se importando com os fins. Basta notar o destaque dado, pelos grandes veículos de mídia, às falhas na segurança e disciplina (motins, fugas e crimes) e como essas podem alcançar o patamar de verdadeiros escândalos. Em contrapartida, o engajamento do ex-presidiário na vida livre e sua reincidência no crime são dados ignorados, mesmo representando a falha ou o sucesso da pena.

A consequência dessa seletividade da sociedade livre é o descaso da administração penitenciária com os fins da pena. Passa-se a priorizar a manutenção da segurança e da disciplina, obtendo, apenas em segundo plano, os fins originais.

E qual melhor maneira de impedir fugas e outras desordens que não cerceando a autonomia e controlando cada movimento do interno? Evidencia-se o conflito com a atividade terapêutica, afinal, essa precisa de "encorajamento do auto-respeito, do senso de responsabilidade, da autoconfiança, do espírito de independência e de criatividade."

\footnotetext{
${ }^{9}$ THOMPSON, Augusto. A Questão Penitenciária. p. 8.

${ }^{10}$ THOMPSON, Augusto. A Questão Penitenciária. p. 9.
} 
O que acaba por ocorrer é um enfoque no viés punitivo da pena, pois esse pode ser executado - e anseia-se ${ }^{11}$ por executa-lo - junto da manutenção da segurança e da disciplina, descartando efetivamente a atividade terapêutica. E, por mais que soe como pleonasmo ou obviedade para alguns, ainda é necessário enfatizar que a consequência disso não é a ressocialização do condenado. Pelo contrário, o Castigo age, essencialmente, na direção oposta à da ressocialização.

O Castigo não desperta no castigado o sentimento definido por Nietzsche como a má-consciência ou o remorso. Esse é forjado pela repressão das vontades e sentimentos "originários" mediante sua interiorização voluntária. Valendo-se de uma opressão externa, o Castigo faz diferente, ele condiciona a atividade do castigado àquela resposta violenta, ele domestica. Faz-lhe pensar "algo aqui deu errado" e não "eu não deveria ter agido assim”.

O que em geral se consegue com o castigo, em homens e animais, é o acréscimo do medo, a intensificação da prudência, o controle dos desejos: assim o castigo doma o homem, mas não o torna "melhor" - com maior razão se afirmaria o contrário. ${ }^{12}$

Nessa "domesticação", o Castigo confere cautela ao condenado, que endurece, torna-se resistente aos maus-tratos e se adapta à realidade que lhe cerca. Sua nova prudência não o ensina a não mais cometer crimes, mas sim que, se for cometê-los, deve cometê-los melhor ${ }^{13}$.

\section{A inefetividade da domesticação.}

A domesticação a qual o condenado é submetido não é de forma nenhuma incomum ou impressionante. Afinal, o que temos ali é um

\footnotetext{
${ }^{11}$ O Castigo, que se inclui no viés punitivo da pena, é desejado pela sociedade livre e, também, pelos membros da administração penitenciária, por motivos que veremos adiante.

${ }_{12}$ NIETZSCHE, Friedrich. Genealogia da Moral: Uma polêmica. São Paulo: Companhia de Bolso, 2009. p. 66.

${ }^{13}$ Numa hipótese de ressocialização, a atividade terapêutica ensinaria ao condenado os valores da sociedade livre, explicando-os de forma que o detento os compreendesse e aceitasse, internalizando-os. Assim, não haveria mais a possibilidade de delinquência, uma vez que o cumprimento das regras sociais seria sentimento originário dele.
} 
indivíduo ingressando em um novo grupo, um novo maquinário de poder e sendo a ele gradualmente assimilado; assim como ocorre com toda pessoa que entra numa instituição disciplinar desconhecida. Para Foucault, a prisão não passa de: "um quartel um pouco estrito, uma escola sem indulgência, uma oficina sombria, mas levando ao fundo, nada de qualitativamente diferente" 14 .

Ao processo de assimilação do indivíduo na penitenciária, Donald Clemmer $^{15}$ deu o nome de prisionização, nomenclatura também adotada por Thompson ${ }^{16}$. O termo indica a adoção, em graus diferenciados, da cultura geral da penitenciária - seus hábitos, costumes e formas de pensar ou, como pode-se também dizer, sua transformação em membro da comunidade prisional.

De fato, todo indivíduo partícipe da comunidade prisional, seja ele guarda, diretor ou interno, sofre os efeitos da prisionização. A diferença fica em sua posição na escala hierárquica da instituição disciplinar ou, em outras palavras, se ele passa o Castigo ou se o recebe.

O questionamento que resta é qual a efetividade desta prisionização na prevenção da reincidência? Já foi constatado que ela não regenera o condenado, isto é, não o ensina o erro dos seus caminhos e o indica como levar uma vida de virtudes, porém, se a domesticação for capaz de intimidálo e condicioná-lo a não voltar a delinquir, alguns poderiam argumentar que ela é um sacrifício ${ }^{17}$ válido. Assim, pergunta-se: a prisionização é eficiente?

Não, não é.

\footnotetext{
${ }^{14}$ FOUCAULT, Michel. Vigiar e Punir. p. 196.

15 CLEMMER, Donald. "Prisionization" em: JOHNSTON, SAVITZ E WOLFGANG. The Sociology of Punishment \& Correction. $2^{\mathrm{a}}$ Edição. Nova Iorque: Jon Wiley and Sons, 1970. p. 579-483. Apud THOMPSON, Augusto. A Questão Penitenciária. p. 23.

${ }^{16}$ THOMPSON, Augusto. A Questão Penitenciária. p.23.

17 "Sacrifício", pois a prisionização é feita às custas da dignidade humana, tanto do detento que é castigado quanto do povo que assiste a tudo e demanda por mais Castigo.
} 
A prisionização do condenado consiste em sua adaptação à vida no cárcere, à internalização de suas regras e seus preceitos. O sujeito "prisionado" sabe quando deve comer, quando deve dormir e quando deve trabalhar. Compreende que deve obedecer quando um guarda lhe dá uma ordem e entende os malefícios e benefícios de desobedecê-la. Ele pode não ter experimentado, mas já ouviu sobre os terrores das solitárias. Ele não pretende delinquir, ou, se pretende, o fará sem nenhum estardalhaço e com a cooperação das pessoas certas.

O que ele não sabe é como lidar com a realidade que o fez delinquir e o mandou para a prisão, no inicio de sua desventura.

$\mathrm{O}$ argumento pode vir como uma surpresa para alguns defensores do discurso ressocializador oficial, mas a penitenciária não é um microcosmos da sociedade livre. Suas regras e conceitos, internalizados pelos detentos, não são nada como os da vida extramuros; na realidade, eles são antagônicos na maior parte do tempo.

Ou seja, na prática, o discurso oficial tem a expectativa absurda de que um criminoso, por estar submisso e acostumado a um regime carcerário severo, comportar-se-á como não-criminoso na sociedade livre.

Destrinchando a ilogicidade do raciocínio, Thompson elenca duas incongruências do discurso oficial como fundamentais ${ }^{18}$ : (1) ajustar uma pessoa a hábitos e costumes de forma coercitiva não oferece segurança de que tais ajustes permanecerão uma vez que as coerções sejam removidas; (2) o mundo da prisão é tão diferente do mundo livre que nada apreendido ali a ajudaria do lado de fora.

Por essas razões, a adaptação do condenado à prisão não é sinônimo de adaptação à vida livre. E, por essas mesmas razões, na vasta maioria dos casos, ela pode ser percebida como uma desadaptação à vida livre.

\footnotetext{
${ }^{18}$ THOMPSON, Augusto. A Questão Penitenciária. p.12.
} 
E como poderia não ser? A realidade carcerária é uma versão subversiva e corrupta daquela que a sustenta. Abandonada a finalidade ressocializadora, a administração vacila entre rígida e leniente, aplicando castigos e fazendo vista grossa ante a eterna criminalidade intramuros, em prol de manter a ordem interna e afastar os olhos externos. É um ambiente confuso; ao mesmo tempo em que se perde o direito à intimidade, submetese a revistas e à vexames, tem-se a personalidade reduzida à números e pune-se o mínimo sinal de desrespeito pela autoridade que não explica suas decisões e favorece as ações quase despóticas dos guardas, permite-se o tráfico de drogas, organizam-se e reúnem-se facções, ignora-se estupros, comanda-se crimes externos e crê-se acima da lei.

As regras da penitenciária punem aquele que as quebram, drenam aquele que as seguem e favorecem aquele que as dobram. Cada detento então assume um papel, de acordo com sua adequação à vida no cárcere. “Arrochadores", “cadeieiros", “cagüetes", "negociantes” e outros ${ }^{19}$, há um personagem para todos entre os muros da prisão - um personagem que não funciona, não existe, fora daquelas paredes.

O que não há é a opção de se manter integro. $\mathrm{O}$ novato não tem escolha que não entrar em um daqueles personagens, pois é o ato de escolher um papel para si que lhe garantirá sua sobrevivência. Por mais que ele resista, eventualmente terá de aceitar que aquela é a sua realidade dali em diante e deverá se adequar a ela. Do contrário, o peso da perda da vida livre o esmagará, os guardas o colocarão de exemplo, o diretor o ignorará, os outros detentos o abusarão e ele não aguentará todo o tempo de sua estadia.

Por isso todos acabam por se prisionizar. Porque eles percebem que na penitenciária as regras são outras e vale de tudo para sobreviver.

\footnotetext{
${ }^{19}$ THOMPSON, Augusto. A Questão Penitenciária. p.83-89.
} 
Uma vez prisionizado, uma vez que o Castigo the foi aplicado note-se, o Castigo aplicado na maior parte das vezes sem nenhuma pitada de "ressocialização" - o individuo está, de certa forma, corrompido. Ele aprendeu as durezas da vida e algo dentro dele se tornou frio. Ele aprendeu o que fazer para sobreviver e nunca vai se esquecer disso. E as consequências desse aprendizado podem ser muitas.

Como dito, não há garantias que o detento que inibia (se ele realmente inibia) sua vontade de delinquir continue inibindo-as uma vez livre do ambiente disciplinar da penitenciária. Na verdade, o que há são incentivos para que ele delinqua. Afinal, quando o ex-detento deixa a penitenciária, ele tem o dever de reinserir-se na sociedade livre que o expulsara - às vezes sob a pena de voltar ao cárcere. Ele deve, entretanto, realizar essa árdua tarefa com pouco ou nenhum auxílio do Estado, ao mesmo tempo em que encara as mesmas adversidades que o enviaram à prisão e outras novas. Simultaneamente, ele sabe que pode sobreviver ao Castigo, ele aprendeu novas técnicas, ele fez novos contatos. Ele crê na impunidade, tem a necessidade e não teme o Castigo.

Está pronta a receita para um novo crime.

Há aqueles que se salvam, claro, mas não por mérito da penitenciária. Esses apenas têm a agradecer a alguma força externa, como o apoio familiar ou a crença e o suporte de uma religião, e a sua própria força de vontade. É necessário muito de uma pessoa para viver - e até cometer os horrores que ocorrem na penitenciária sem mudar o âmago de seu ser, sem se adequar a ela. É como está em Papillon, de Henri Charrière: " $O$ caminho da podridão não deixou marcas degradantes em mim. Sobretudo porque, na realidade, creio, nunca me adaptei a ele."20

\footnotetext{
${ }^{20}$ CHARRIÈRE, Henri. Papillon. Paris: Ed. Robert Laffont, 1969. p. 509 Apud THOMPSON, Augusto. A Questão Penitenciária. p. 13.
} 
Claro que, mesmo esses, enfrentam uma série de problemas quando deixam a penitenciária. Provavelmente terão maior facilidade em combatêlos, afinal contarão com o mesmo suporte familiar ou religioso que tiveram dentro prisão e esse já teria se provado útil. Entretanto, é inegável que enfrentarão todos os problemas decorrentes do estigma do ex-presidiário.

\section{As marcas da penitenciária.}

A prática da marcação dos condenados pode ter sido abolida junto dos suplícios, mas os ex-presidiários não estão livres de serem estigmatizados pela sociedade. Suas fichas de antecedentes criminais, seus "Nada Consta" ou a mera repercussão de seu crime na mídia ou na comunidade, tudo contribui para que o rótulo de "criminoso" lhes acompanhe pela vida. Em outras palavras, a marcação pode ter acabado, mas não a infâmia.

A infâmia é um sinal da desaprovação pública, que priva o culpado da consideração, da confiança que a sociedade tinha nele e dessa espécie de fraternidade que une os cidadãos de um mesmo país. ${ }^{21}$

As consequências diretas da infâmia são diversas e acompanham todo ex-presidiário ao deixar a penitenciária. Ela o impede de conseguir um bom trabalho e um bom pagamento; o faz receber olhares tortos na rua e faz as pessoas segurarem seus pertences junto ao corpo, quando ele passa; o afasta de seus amigos e entes queridos e o impossibilita de criar novos laços com a comunidade. A infâmia mantém e, de certa forma, aumenta sua distância da sociedade, que continua a puni-lo e condena-lo por crimes já pagos.

Isso é, no mínimo, contraditório. Afinal, se o discurso oficial da pena entende que a pena pune e ressocializa o condenado, aquele que já passou pela pena já não deve mais ser punido, está apto e deve ser reintegrado à

\footnotetext{
${ }^{21}$ BECCARIA, Cesare. Dos Delitos e das Penas. $2^{\mathrm{a}}$ Edição. São Paulo: Editora Edipro, 2015. p. 64.
} 
corpo social. Entretanto, a mesma sociedade que endossa tal discurso dificulta e impossibilita a reintegração do ex-presidiário, mantendo viva a memória de seu crime e continuando sua punição.

O ex-presidiário enfrenta uma situação de total desesperança, nesse momento. Ele sobreviveu a todas as dificuldades da penitenciária, fora reduzido à objeto, extirpado de intimidade e liberdade, pois acreditava (se é que acreditava) em teria uma segunda chance no lado de fora após "pagar o que devia" - não era o caso.

A única coisa que a sociedade lhe concede é a infâmia e essa só perpetua o Castigo.

O ex-presidiário tem, então, uma escolha: Ou ele conquista - com grandes dificuldades - o seu espaço no corpo social ou ele veste a carapuça que lhe foi dada. Cedo ou tarde, a escolha recai na segunda opção. Afinal, ele já sobreviveu à penitenciária uma vez, ele já aprendeu as regras do jogo e, mais importante, ele não tem mais nada a perder.

Cumpre salientar que este é sim o verdadeiro mal da penitenciária. O estigma que é incutido ao ex-detento é alheio à administração da penitenciária e alheio à sua vontade de se reinserir no corpo social. É uma dificuldade ainda maior àquela que o fez delinquir em primeira instância, o que só o instiga a cometer mais e mais crimes.

É um estigma que existe mesmo na melhor das penitenciárias. Mesmo naquelas em que funcionam projetos sociais, em que trabalham grandes médicos e psicólogos, em que há a vontade de voltar ao mundo extramuros e esse mundo é "perfeito".

O The New York Times publicou ${ }^{22}$, em 1972, uma matéria sobre o sistema penitenciário sueco. Em meio a características que soavam como

\footnotetext{
${ }^{22}$ The New York Times, republicado pelo O Estado de São Paulo, São Paulo, em 23/10/1972. Apud THOMPSON, Augusto. A Questão Penitenciária. p. 132-137.
} 
utópicas para países menos desenvolvidos - como 3.300 detentos no país, prisões sem muros, salários equiparados ao mercado extramuros, assistência pedagógica intensiva e sindicato dos presidiários - um dado destoava: sua taxa de reincidência era extremamente parecida com a dos demais países.

"As condições de vida em nossas prisões são bastante aceitáveis, mas certamente não dissuadem do crime", declarou Lasse Bjorklund, líder da Organização Central dos Presidiários, que já cumpria sua oitava ou nona sentença. "Você se habitua à vida no presídio. Não acho que as prisões possam reabilitar a maioria das pessoas. Qualquer reabilitação depende, principalmente, dos vínculos do recluso coma a sociedade lá fora".

Um detento norte-americano, cumprindo prisão na Suécia, também falou ao jornal que os programas de reabilitação lá empregados diminuíam o sofrimento da prisão, mas pouco faziam para fins de reinserção social. "Veja esses indivíduos", ele disse. "Todos eles já estiveram aqui anteriormente. Alguns deles já estão inclusive planejando voltar. Eles não têm mais nada lá fora."

Compreende-se, então, que a prisionização não é o fator determinante na reincidência, mas sim a questão social por trás da penitenciária. Afinal, mesmo no melhor dos mundos, a administração penitenciária agiu em conformidade com o discurso ressocializador, os exdetentos permanecem sem ser aceitos na sociedade livre e acabam retornando à penitenciária.

Vale apontar, desde já, que esse dado não caiu em ouvidos surdos.

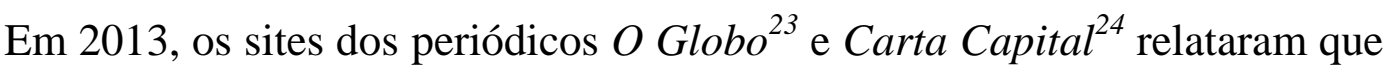
a Suécia estava fechando as portas de quatro de seus presídios por falta de

\footnotetext{
23 O GLOBO. Suécia fecha quatro presídios por falta de condenados. $<$ http://oglobo.globo.com/mundo/suecia-fecha-quatro-presidios-por-falta-de-condenados10769563> Acesso em: 21/11/2016.

24 BOCCHINI, Lino. Suécia fecha 4 prisões e prova: a questão é social. $<$ http://www.cartacapital.com.br/sociedade/suecia-fecha-4-prisoes-e-prova-mais-uma-vez-aquestao-e-social-334.html> Acesso em: 21/11/2016
} 
presos. A razão disso fora atribuída a uma mudança de enfoque na questão penitenciária - começou-se a trabalhar também na questão social do crime. Com maior apoio do Estado ao ex-detento, com a decretação de penas mais curtas e leves e a aplicação de penas alternativas que visavam a reintegração do condenado, a Suécia teve sucesso em diminuir os efeitos do estigma do ex-presidiário e diminuir sua taxa de encarceramento em $6 \%$.

Mas o Brasil não é a Suécia. Aqui, não somente a população carcerária e a taxa de reincidência são maiores, como também é a prisionização. $\mathrm{O}$ que leva à segunda marca que carrega o ex-detento: a desadaptação à vida livre.

Não é nenhuma história incomum. $\mathrm{O}$ individuo comete um homicídio. É condenado a uma pena longa e vai ao cárcere. Lá, enfrenta dificuldades, mas acaba por se prisionizar. Aos poucos perde contato com a vida que tinha do lado de fora daqueles muros e passa a conhecer cada canto escuro da penitenciária. Aquela era sua nova casa e aquele era seu novo mundo. Trinta anos se passam. Quando entrara lá, mal tinha essas três décadas em idade, mas, agora, tem mais de o dobro delas. O mundo mudou e ele, que já nunca se encaixou direito, se encaixa pior ainda nele. Tenta aplicar o que sabe, aquilo que o fizera sobreviver até então, mas não dá certo. Passara tanto tempo obedecendo ordens e apanhando por descumprilas que se esquecera como era ter iniciativa, de como era pensar por si mesmo. Falha nas tarefas mais simples e luta para ter alguma comida, algum abrigo. Perde o emprego como empacotador e é reduzido a um nada. Sabe que não pode retornar ao crime - se é que se pode chamar de retorno quando se teve um único dia de crime, - pois já está velho demais para isso e sua saúde não é das melhores, mas talvez possa retornar à penitenciária. Lá ele trabalhava na lavoura e era alguém. Tinha abrigo, comida e alguns amigos. Nada do melhor, mas já era alguma coisa. Então decide se armar quando vai visitar seu juiz e é preso mais uma vez. Volta para sua casa. 
Pode parecer uma história genérica e fictícia, mas este é um relato bastante comum entre detentos reincidentes. Mudando um pouco os fatos, removendo a coragem de proceder com a nova ação criminosa, poderia ser a história de Brooks Halten, personagem do filme Um Sonho de Liberdade, que, após 42 anos preso, é liberado e comete suicídio.

A internalização de um ambiente tão nitidamente diferente do mundo livre o desadapta a ele. Lá, o detento é condicionado a obedecer ordens e a somente obedecer ordens, sendo aos poucos drenado de qualquer autonomia. Ele aprende somente a reagir, não a agir e é furtado de qualquer vontade própria que já tenha tido.

Kant define "aquilo que faz do homem homem" como a capacidade do homem de se autodeterminar, de pensar por si mesmo e trilhar seus próprios caminhos. Isto é, na sua - amplamente difundida - concepção, é o livre-arbítrio que nos faz humanos.

Pode-se dizer, portanto, que o que ocorre entre as paredes da penitenciária, esse bastião da sociedade que deveria iluminar e retificar os indivíduos, é nada menos que o furto indiscriminado e institucionalizado da humanidade de dezenas de milhares de indivíduos.

Então, se nada até agora fora o bastante para provar a deficiência da penitenciária, que esse fato sirva como prova de seu absoluto fracasso. 


\section{Capítulo 2 - Do Castigo na Sociedade}

\section{Da Vontade de Castigar.}

Tendo em mente os malefícios da prisão e da domesticação dela proveniente, há de imaginar as razões de sua manutenção. Como pode uma instituição tão apodrecida perdurar em nossa sociedade por tanto tempo? Seria a realidade ainda desconhecida por todos ou a verdade é que ninguém se importa?

A realidade do cárcere é, em maior parte, conhecida das grandes massas. É bem difundido que a ressocialização pregada pelo discurso oficial da pena é uma ilusão ou, no mínimo, um sonho que raramente se materializa. Deposita-se alguma esperança que o medo dos horrores da penitenciária afastará os indivíduos do crime e que os traumas deles resultantes os afastarão da reincidência, mas não há expectativa de um aprendizado e de uma reforma do condenado. Em verdade, pouco importa se o criminoso voltará a delinquir, desde que ele seja punido.

Quando presidiários da penitenciária de Pedrinhas, na capital do estado do Maranhão, liberaram na internet, em Janeiro de 2014, um vídeo em que expunham as três cabeças decapitadas de três outros detentos como troféus resultantes de uma disputa interna em sua facção criminosa ${ }^{25}$, Jair Bolsonaro, deputado federal pelo estado do Rio de Janeiro, disse:

"A única coisa boa do Maranhão é o presídio de Pedrinhas. É só você não estuprar, não sequestrar, não praticar latrocínio que tu não vai para lá. Vai dar vida boa para aqueles canalhas?", 26

Sua afirmação foi recebida com o choque que lhe é devido e dividiu opiniões. Houve aqueles que a refutaram e se revoltaram, mas também

\footnotetext{
${ }^{25}$ SCOLESE, Eduardo. Presos filmam decapitados em penitenciárias no Maranhão; veja vídeo. $<$ http://www1.folha.uol.com.br/cotidiano/2014/01/1394160-presos-filmam-decapitados-empenitenciaria-no-maranhao-veja-video.shtml> Acesso em: 21/11/2016.

${ }^{26}$ BORGES, Bruna; CALGARO, Fernanda. A única coisa boa do Maranhão é o presídio de Pedrinhas, diz Bolsonaro. <http://noticias.uol.com.br/politica/ultimas-noticias/2014/02/11/minhaproposta-e-defender-direitos-da-maioria-e-nao-da-minoria-diz-bolsonaro.htm $>$ Acesso em: 21/11/2016.
} 
houve quem a apoiou e aplaudiu. Os que clamaram por direitos humanos, clamaram também pela tomada de medidas a fim de restaurar a ordem na penitenciária e punir os responsáveis pelos assassinatos. Os que comemoraram, não pediram por reparos na administração, mas ainda demandaram que a justiça fosse feita.

O fato foi um episódio extremo e por isso a população se viu dividida; entretanto, ela não se dividiu quanto a um aspecto: a necessidade de um Castigo.

Uma nova punição, ou ainda, um aumento da pena que o detento já cumpria teria algum efeito em ressocializa-lo? Poderia ao menos traumatiza-lo a ponto de não mais cometer crimes? Certamente que não. Puni-lo mais não resolveria a disputa de facções, a falta de recursos ou a superlotação do presídio, na verdade, só intensificaria o problema, pois o manteria lá mais tempo e o endureceria ainda mais. Entretanto, todo o povo exigiu dessa forma, assim como exige o encarceramento de todo criminoso que desponta na sociedade livre, pouco importando os efeitos de seu Castigo.

Mas por que castigam?

(...) por raiva devida a um dano sofrido, raiva que se desafoga em quem o causou; mas mantida em certos limites, e modificada pela ideia de que qualquer dano encontra seu equivalente e pode ser realmente compensado, mesmo que seja com a dor do seu causador. ${ }^{27}$

As raízes dessa vontade estão arraigadas na noção da relação contratual entre credor e devedor. Esse é, talvez, um dos mais antigos conceitos dentro do direito e é tão básico e intuitivo quanto a mais simples das leis da física: para toda ação há uma reação em sentido oposto ${ }^{28}$. Portanto, toda ação danosa gera um crédito para aquele que foi prejudicado,

\footnotetext{
${ }^{27}$ NIETZSCHE, Friedrich. Genealogia da Moral. p. 48.

${ }^{28} 3^{\mathrm{a}}$ Lei de Newton: A toda ação há sempre uma reação oposta e de igual intensidade: as ações mútuas de dois corpos um sobre o outro são sempre iguais e dirigidas em sentidos opostos.
} 
permitindo-o exercer uma reação equivalente, em reparação, naquele que o prejudicou.

O crime é uma ação danosa extremamente complexa, uma vez seu dano possui duas facetas: a da vítima direta, que teve seu direito individual violado, e da sociedade como um todo, que teve suas leis e sua ordem violada. Dessa forma, a "regra" da equivalência só será obedecida quando a vantagem obtida indevidamente for compensada e a ordem social for reafirmada; ou seja, por conta da complexidade do dano da ação, a reação deve ser mais intensa.

Entretanto, como reagir a um dano causado à ordem social? Como restituir a vítima em seu prejuízo quando a coisa é irrestituível (casos de morte ou furto onde o bem foi perdido ou consumido)?

A primeira resposta encontrada pela sociedade é simples, mas soa estranha e rude aos ouvidos daqueles que olham com otimismo a natureza humana: com a dor.

"Pergunta-se mais uma vez: em que medida pode o sofrimento ser compensação para a "divida"? Na medida em que fazer sofrer era altamente gratificante, na medida em que o prejudicado trocava o dano, e o desprazer pelo dano, por um extraordinário contraprazer: causar o sofrer (...), ${ }^{, 29}$

Encontra-se a equivalência na substituição da reparação da vantagem obtida pela satisfação íntima de descarregar seu poder sobre um impotente, pelo prazer de maltratar aquele que lhe maltratou. Simultaneamente, tem-se a sociedade se reafirmando, pois, ao fazer chover sua fúria no devedor, ela fornece a mesma satisfação aos seus cidadãos, que atestam, então, por sua força e integridade. "A compensação consiste, portanto, em um convite e um direito à crueldade.",30

\footnotetext{
${ }^{29}$ NIETZSCHE, Friedrich. Genealogia da Moral. p. 50.

${ }^{30}$ Ibid. p. 50.
} 
Há algo de festivo no ver-sofrer e ainda mais no fazer-sofrer. Não à toa os coliseus romanos eram lotados e, hoje, igualmente são os octógonos de UFC; mas pelo mesmo motivo também eram os suplícios, a guilhotina e os enforcamentos. Há satisfação em ver o outro sofrendo e uma satisfação mil vezes maior em ver aquele que lhe prejudicou - como individuo ou como sociedade - sofrer. Logo, o Castigo não poderia conter elemento diferente.

De fato, o humanismo surgido com o Iluminismo atenuou as penas e mudou seu foco, porém ele não retirou o Castigo de sua fórmula. Como já exposto, a penitenciária tem, em si, muito de suplício, pois ela é essencialmente composta pelo Castigo e a "festa" que ele contém. Se um delinquente é preso, a população comemora; se é absolvido um inocente que o povo crê criminoso, já surgem aqueles que falam de pegar em armas.

Não, o Castigo é essencial à sociedade. Ele é o objeto da dívida, é o meio do qual o credor se vale para satisfazer seu crédito. É a ânsia da sociedade por justiça, é a sua vingança pelo sofrimento causado. É a demanda social por igualdade e respeito, é a oportunidade daquele que nada tem de participar do direito dos senhores ${ }^{31}$ de ter, finalmente, alguém como seu inferior.

Para o desgosto de muitos intelectuais, o Castigo é a vontade da sociedade e ele não pode ser retirado dela.

\section{O Estado e o Castigo.}

Se a sociedade deseja o Castigo, uma coisa é certa, haverá Castigo.

O sentimento de injustiça daquele que se viu pessoalmente ou coletivamente prejudicado busca sossego de diversas formas. A primeira delas, normalmente, é a lícita, isso é, através de amparo junto a autoridade

\footnotetext{
${ }^{31}$ Ibid. p. 50.
} 
estatal. Quando essa falha, não é necessário muito para que o individuo recorra à difamações, agressões, linchamentos, homicídios ou revoltas. Não há esperanças de parar o Castigo; a sociedade o perpetrará, de uma forma ou outra - ou, como frequentemente é colocado, "a justiça será feita".

Além disso, é perceptível, historicamente, que a ânsia pelo Castigo se manifesta, normalmente, de forma violenta e desconhece os limites da lei. Basta observar as pequenas vinganças pessoais arbitradas por membros ordinários da sociedade ou mesmo os grandes acontecimentos como o fim do Czarismo Russo em 1917 e as Manifestações de Julho de $2013^{32}$. O credor não mede esforços para sanar sua dívida, mesmo que uma lei ou outra seja quebrada no processo - afinal, o devedor já a quebrou mesmo, não é?

A ira do credor prejudicado, a comunidade, o devolve ao estado selvagem e fora da lei do qual ele foi até então protegido: afasta-o de si - toda espécie de hostilidade poderá se abater sobre ele. ${ }^{33}$

É neste momento que o Estado deve fazer sua aparição. Entendendo o Castigo buscado pela sociedade como inevitável e perigosamente cruel, cabe ao Estado se apropriar dele, a fim de regula-lo, para o bem da sociedade e para conservar seu próprio poder.

O Estado que não se apossa do Castigo permite que ele corra preocupantemente livre. Isso, pois o povo, que dele se apossaria, desconhece os freios da imparcialidade e da proporcionalidade e é guiado somente pelo impulsivo fervor dos apaixonados. Seus Castigos seriam dos mais violentos para que os lesados pudessem descarregar toda a frustração sofrida e ainda mais, banqueteando-se no prazer do sofrimento alheio. E, na

\footnotetext{
${ }^{32}$ Ambos os eventos tem fundamento em grandes insatisfações do povo que permaneceram sem respostas por seus governantes, de forma que aqueles tiveram de tomar medidas drásticas para receber seus créditos. No primeiro caso, as injustiças residem nas insatisfações geradas pela Primeira Guerra Mundial e o Domingo Sangrento, ambos episódios não adereçados pelo Czar, que acabou morto, junto de toda sua família. No segundo, o povo se sentiu injustiçado pela apatia do governo frente aos crescentes escândalos de corrupção e seu continuo descaso frente à sociedade.

${ }^{33}$ NIETZSCHE, Friedrich. Genealogia da Moral. p. 56.
} 
repetição, seus espíritos endureceriam e seus Castigos cairiam na rotina, necessitando de uma nova dose de perversidade.

A gente se habitua aos suplícios horriveis; e, depois de cem anos de crueldades multiplicadas, as paixões, sempre ativas, são menos refreadas pela roda e pela forca do que antes o eram pela prisão. ${ }^{34}$

Rapidamente, o aumento de crueldade ultrapassaria o tênue liame daquilo que bastaria para punir o devedor e, em seu excesso, alcançaria patamares tirânicos. A tirania da sociedade não apenas corresponderia a um abandono do ideal de justiça inicialmente almejado, como também acarretaria consequências graves para todos os envolvidos.

Em primeiro lugar, ocorre o sacrifício da humanidade dos envolvidos. Tanto do condenado, que será punido como se não passasse de um animal, quanto do povo, que, em sua ânsia de sangue, se esquece que está lidando com um igual. Além disso, há uma deslegitimação da autoridade estatal, uma vez que ela permite que ocorram tais injustiças. Consequentemente, os mais sensatos terão receio em aplicar o Castigo demandado pela sociedade e os criminosos odiarão ainda mais o povo que lhes segregou e, agora, injustiçou, além do Estado que lhes abandonou à própria sorte.

O Estado que deixa de aplicar o Castigo - e consequentemente permite que o povo se aposse dele - é, talvez, mais mal visto do que aquele que exagera em sua aplicação. Por mais antiga que seja a corrente de pensamento, o Contratualismo talhou seus princípios suficientemente fundo nos corações dos indivíduos para que sempre lembrassem que a proteção dos cidadãos é a obrigação primária de um Estado. Falhando nesta tarefa, ele perde sua credibilidade e dá espaço para que sua autoridade seja contestada por meio de poderes paralelos e insurreições.

Faz-se necessário, então, o Castigo-instituição, aplicado e regulado pelo Estado. É dever da autoridade estatal determinar os meios mais

\footnotetext{
${ }^{34}$ BECCARIA, Cesare. Dos Delitos e Das Penas, p. 54
} 
eficazes para acalmar as demandas de justiça da sociedade e, ao mesmo tempo, menos cruéis ao corpo do condenado - possibilitando seu retorno ao seio da sociedade. Somente através de sua intervenção é possível garantir que haverá o distanciamento necessário entre julgador e causa para que essa seja resolvida sem a interferência das paixões e preconceitos do povo; para que um Castigo moderado e eficiente seja aplicado; para evitar a implosão do Estado e de toda sociedade consigo.

\section{A Deslegitimação da Penitenciária como Castigo.}

A despeito da autoridade estatal ter assumido a responsabilidade pelo Castigo, as formas de punir jamais permaneceram estáticas. Primeiro ele se valeu das penas corporais, com normas como a Lei de Talião, e do ostracismo, tempos depois, foi a vez dos suplícios e, enfim, chegou a era das prisões. Adotando um olhar histórico, pode-se afirmar que tais transformações foram até frequentes e que, curiosamente, sempre descartavam suas versões pretéritas. Mas, a despeito das justificativas históricas específicas para cada mudança, uma pergunta ainda se faz digna: por que mudar para começo de conversa?

A sociedade nunca se deu por absolutamente satisfeita com forma de Castigo alguma. É como diz o famoso ditado: "não se pode agradar a todos". Sempre existem críticos à ordem vigente e isso não é surpresa, a maré começa a virar quando os críticos aumentam em quantidade e o Castigo implantado passa a ser compreendido pela sociedade como "injusto".

Foi o que aconteceu, por exemplo, com os suplícios, no final do Séc. XVIII e inicio do Séc. XIX. Sua atrocidade passa a ser vista como excessiva, o crime ganha as honras de resistência e o delinquente a alcunha de mártir ou, até mesmo, herói. A sociedade repudia a punição estatal e a 
confunde com o crime que ela mesma tentou coibir. A forma de punir do Estado perde sua fundamentação racional e deve se reinventar.

A esta perda de racionalidade podemos dar o nome de deslegitimação. De acordo com Eugenio Raúl Zaffaroni, "por legitimidade do sistema penal entendemos a característica outorgada por sua racionalidade",35 e são características essenciais à racionalidade a (1) coerência interna do discurso jurídico-penal e o (2) valor de verdade quanto à operatividade social.

A coerência interna exige que o discurso jurídico-penal faça sentido consigo mesmo e que possua um mínimo de fundamentação antropológica para se justificar, ou, em outras palavras, exige que suas determinações tenham um sentido que possa ser defendido pela sociedade. Afinal, o direito serve ao homem, e não o contrário.

Fica clara a negação da coerência interna do discurso jurídico-penal quando se esgrimem argumentos tais como: "assim diz a lei", "a faz porque o legislador o que", etc. Estas expressões são frequentemente usadas em nossa região e implicam a confissão aberta do fracasso de qualquer tentativa de construção racional e, por conseguinte, legitimadora do exercício de poder do sistema penal. ${ }^{36}$

Quanto ao valor verdade, o discurso deve ser socialmente verdadeiro em duas esferas: a abstrata e a concreta. Na primeira, ele deve ter um sentido prático; deve ser um discurso que emprega um meio adequado ao fim pretendido. $\mathrm{Na}$ esfera concreta, ele deve ser efetivo; as pessoas que o operam devem fazê-lo de acordo com os seus ditames.

Um discurso jurídico-penal que careça de qualquer um destes atributos se prova insustentável a longo-prazo. Aos poucos, ele se prova um meio de controle social ineficiente e, para evitar a usurpação do Castigo pela população e consequente derrubada do Estado, deve ser substituído.

\footnotetext{
${ }^{35}$ ZAFFARONI, Eugenio Raúl. Em busca das Penas Perdidas: a perda da legitimidade do sistema

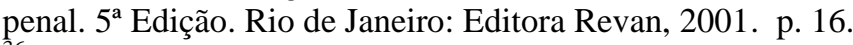

${ }^{36}$ Ibid. p. 17.
} 
Foi assim que ocorreu com os suplícios e é assim que está acontecendo com as penitenciárias.

As frequentes notícias de inquéritos sem solução, de corrupção, de prisões relaxadas - por mais que sejam prisões cautelares, - de julgamentos que não têm fim, de penitenciárias com "benefícios" ao detento, de criminosos reincidentes têm um impacto na sociedade. O povo busca por alguém para culpar e dificilmente o reconhecerá que o verdadeiro culpado é o próprio sistema penal, podre por natureza.

Primeiro, desacreditam na autoridade estatal. A sociedade para de crer que as autoridades policiais e judiciais estão fazendo seu trabalho como devem e questionam a forma que o legislativo construiu o sistema. Rotulaos como incompetentes e preguiçosos ou até mesmo como corruptos afinal, todos podem ver que os crimes estão ali, como ninguém faz nada a respeito? Ou ainda, como insistem em penalizar crimes como aborto com consentimento ou casa de prostituição enquanto tem tantos outros crimes "mais importantes" ao redor?

Mas logo se percebe que não é bem assim e a culpa muda de mãos. Culpa-se os direitos humanos, que protegem os coitadinhos, as prescrições, que se aproveitam da lentidão do Judiciário, a mídia, que impede a autoridade de dar o que os bandidos "merecem". Eventualmente, se reconhece que o sistema é falho e as pessoas (maus-caracteres!) se aproveitam dele.

Cansada de desse sistema-penal e dessa autoridade que com ele coaduna, a sociedade se apossa do Castigo. Linchamentos públicos, criminosos amarrados em postes, justiceiros aplaudidos, protestos populares, tortura em delegacias, em presídios, homicídios em favelas, em ruelas e em qualquer outro lugar longe de olhos estranhos. Para a sociedade, mais importante que culpar alguém ou resolver o problema, a "justiça” deve ser feita. 
E assim se vai a coerência interna das normas, o valor verdade abstrato e concreto, a racionalidade do sistema penal e toda a sua legitimidade. Para os olhos do povo, há a impunidade, a ausência de Castigo, e isso é inaceitável. Como todo bom credor, a sociedade exigirá seu quinhão cedo ou tarde.

E, na terra da impunidade, quem faz a justiça do povo, é ele mesmo. 


\section{Capítulo 3 - Das Outras Formas de Castigo}

\section{O Abandono da Hipocrisia.}

Não é difícil compreender as razões da prisão-Castigo ser tão facilmente aceita. A penitenciária não apenas se adequava perfeitamente à sociedade disciplinar que se instalava no Século XIX, como também respondia às demandas da maior parte daqueles que criticavam os suplícios. Além disso, com seu discurso simultaneamente punitivo e ressocializador, ela se provou capaz de nutrir a sociedade com o sofrimento que anseia e as mentiras que deseja.

Mas, neste ponto do trabalho, as mentiras já foram superadas e enxerga-se as vontades da sociedade com clareza. Foi concluído, até aqui, que: (1) as penitenciárias não ressocializam, só castigam; (2) seu castigo é exagerado, ilegítimo e gerador de criminosos piores; (3) a despeito disso, a sociedade exige que haja Castigo e o buscará por conta própria se necessário; (4) cabe, então, ao Estado administrar o Castigo para garantir a ordem e a paz; (5) entretanto a penitenciária tem se mostrado um meio ineficaz para isso.

Resta a pergunta: e o que fazer a respeito?

A primeira atitude que deve ser adotada é abandonar a hipocrisia. $\mathrm{O}$ hipócrita é o falso, o dissimulado; é aquele que age em desacordo com seus verdadeiros sentimentos e intenções, dissimula-os. A atitude pode ser fruto de má-fé, claro, mas pode também ser tomada por individuo em negação, pois, na maior parte do tempo, a realidade é muito mais dura que a ilusão.

Tal é a atitude dos defensores de nosso sistema penal. Como já colocado, a penitenciária não é e nunca será uma casa de ressocialização, pelo menos não ao mesmo tempo em que se põe como instituição punitiva. O que ocorre intramuros - como todos tem pleno conhecimento - é simplesmente Castigo ou, no mínimo, uma tentativa dele. Não obstante, o 
discurso oficial da lei insiste em afirmar o contrário e permanece enviando condenados a uma provação que não tem esperanças de vencer $\mathrm{e}$ impressionando-se com a inefetividade do sistema penal.

Abandonar a hipocrisia é aceitar que o discurso oficial da lei é um fracasso. Deve-se compreender que a penitenciária jamais funcionará nos padrões de uma atividade terapêutica e que ela só existe pois o Castigo é fundamental à convivência em sociedade. Somente ao abraçar esse conhecimento é possível pensar em como articular uma nova pena e um novo sistema penal.

A partir daí, deve-se dissociar a função punitiva da pena, o Castigo, da atividade terapêutica, a Ressocialização. Deixando de lado a mentira da ressocialização, a pena (e a penitenciária) pode ser remodelada de modo a melhor dar o Castigo - evitando excessos e agindo de forma efetivamente justa. Simultaneamente, pode-se pensar em um novo instituto para a atividade terapêutica, um instituto que não se paute na coerção e na domesticação, um que valorize o individuo e que, de fato, possa reinseri-lo no corpo social.

\section{A Função Punitiva.}

A simbiose entre a sociedade disciplinar e a penitenciária fez dessa uma escolha natural para substituir o suplício, mas isso não significa que tenha sido a única escolha e, tampouco, a melhor. Durante o ocaso do suplício, no Século XVIII, pensadores como Beccaria, Servan, Dupaty, Lacretelle, Duport, Bergasse e outros recusavam o sistema penal "clássico" e clamavam por mudança. A eles recai o crédito pela suavização das penas e a alcunha de "reformadores". 
Os reformadores entendiam que o problema de seu tempo não era oriundo de uma má fundamentação do direito de punir ${ }^{37}$, mas sim uma má economia do poder de castigar. O poder era concentrado no rei, que o distribuía discricionariamente, pouco importando se ficaria concentrado em algum ponto, se seus detentores eram capazes, se suas punições eram excessivas ou se entrariam em contradição entre si. Não havia unidade ou moderação, de maneira que sua reforma se especializaria em "não punir menos, mas punir melhor, ${ }^{, 38}$.

Deslocar o objetivo e mudar sua escala. Definir novas táticas para atingir um alvo que agora é mais tênue mas também mais largamente difuso no corpo social. Encontrar novas técnicas às quais ajustar as punições e cujos efeitos adaptar. Colocar novos princípios para regularizar, afinar, universalizar a arte de castigar. Homogeneizar seu exercício. Diminuir seu custo econômico e político aumentando sua eficácia e multiplicando seus circuitos. Em resumo, constituir uma nova economia e uma nova tecnologia do poder de punir: tais são sem dúvida as razões de ser essenciais da reforma penal do século XVIII. ${ }^{39}$

Assim como no passado, nosso sistema padece de uma má gestão do Castigo. Nossos problemas podem não ser de unidade, como foram os dos antigos, mas são de moderação e, ainda, de adequação das penas. Temos um excesso de prisões e um excesso de Castigo entre suas paredes; temos punições ilógicas, punições injustas e ineficazes. Por isso, a proposta dos reformadores nos é interessante, pois envolvem uma optimização da punição e do sistema que a cerca - sistema esse que pode ser o nosso.

Primeiramente, a moderação das penas. "Em matéria de pena o mínimo é ordenado pela humanidade e aconselhado pela política", dizia Duport $^{40}$, sabiamente. Como já colocado, a humanização das penas era (e é) necessária para evitar o endurecimento e a ferocidade de seus espectadores, bem como é fator essencial para um Estado não receber a alcunha de

\footnotetext{
37 Não questionavam, à época, o poder do rei, mas sim a forma discricionária que ele era distribuído e exercido entre os entes governamentais.

${ }^{38}$ FOUCAULT, Michel. Vigiar e Punir. p. 70.

${ }^{39}$ Ibid. p. 76.

${ }^{40}$ DUPORT, A. Archives parlamentaires. Paris: Discurso na Constituinte, 1789. t. X, p. 744. Apud FOUCAULT, Michel. Vigiar e Punir. p. 77.
} 
tirânico. Entretanto, sempre houve (e ainda há) o debate de como se estabelecer o mínimo? De acordo com que medida há de fixar-se a pena?

Os reformadores defendiam que as consequências do crime deveriam pauta-la. Deixando de lado os efeitos materiais - como o bem perdido em um furto ou a vida ceifada em um homicídio - o prejuízo que o crime traz à sociedade é apenas um: a desordem, o escândalo por ele suscitado. Dessa forma, nada mais correto que fixar uma pena que gere a quantidade de ordem necessária para restaurar a harmonia.

Não se trata de uma Lei de Talião, de forma alguma. Era-lhes sabido que nenhum grito de terror traria um morto de volta de sua cova ou desfazeria outra ação passada. Não se argumenta por uma pena que vise a ofensa passada, que se tenha foco vingança dos ofendidos; pelo contrário, defende-se que a pena deve mirar nas ofensas futuras, restaurar a ordem de tal forma que o criminoso e outros malfeitores não tenham vontade de recomeçar, pois o crime original não gerou consequências para a sociedade. Trata-se, no final de contas, de uma pena cujo Castigo seja eminentemente reparador, pois é somente através da reparação que se acalma os ânimos populares, que não se gera ressentimentos e que se previne futuros crimes.

Mas a diferença é que a prevenção que se esperava como efeito do castigo e de seu brilho - portanto de seu descomedimento - tende a tornar-se agora o princípio de sua economia, e a medida de suas justas proporções. É preciso punir exatamente o suficiente para impedir. Deslocamento então na mecânica do exemplo: numa penalidade de suplício, o exemplo era a réplica do crime, devia, por uma espécie de manifestação geminada, mostra-lo e mostrar ao mesmo tempo o poder soberano que o dominava; numa penalidade calculada pelos seus próprios efeitos, o exemplo deve se referir ao crime, mas da maneira mais discreta possível; indicar a intervenção do poder mas com a máxima economia, e no caso ideal impedir qualquer reaparecimento posterior de um e outro. $O$ exemplo não é mais um ritual que manifesta, é um sinal que cria obstáculo. ${ }^{41}$ (grifos meus)

Sob esse jogo de sinais-obstáculos esconde-se a mais interessante proposta: a individualização da pena com base nas características singulares de cada criminoso. A ideia é que o Castigo não é igual para todos; a multa

\footnotetext{
${ }^{41}$ FOUCAULT, Michel. Vigiar e Punir. p. 79.
} 
não é temível para o rico, tampouco é a infâmia para o reincidente ou mesmo a prisão para aquele que já está encarcerado. Os efeitos do crime também divergem de acordo com seu agente; o crime de um político é mais nocivo para a sociedade que o de um mendigo. Já que o Castigo quer satisfazer os ânimos feridos e prevenir a reincidência, ele precisa considerar quem o criminoso é em seu íntimo e como melhor afetá-lo.

Em um primeiro momento, esta estratégia parece ir diretamente de encontro ao princípio da codificação, base do direito penal moderno, mas isso não a desqualifica. Do ponto de vista de uma economia do poder de punir, pôr-se-ia em circulação um sistema de Castigo perfeitamente ajustado, sem excessos ou lacunas, e extremamente eficiente. Um rico pensaria duas vezes antes de cometer crimes milionários, pois não bastaria cumprir alguns anos de reclusão para aproveitar de seus ganhos; um condenado de crime racial não pensaria que seu delito valeu a pena, pois faria trabalhos comunitários para a comunidade ofendida; um ladrão indigente trabalharia e aprenderia o valor do bem furtado, ao invés de simplesmente ter anos de oportunidades perdidos em uma cela. Esta individualização é, na verdade, o derradeiro objetivo de qualquer código.

A individualização que temos hoje não passa de uma mentira quando comparada àquela idealizada pelos reformadores. Temos uma única espécie de pena prevista para todos os crimes - uma pena cujo bem-jurídico atingido é sempre o mesmo, sempre a liberdade - e essa não possui qualquer vínculo lógico com o delito que pune. A pena passa, então, a sensação de arbitrariedade e tudo aquilo que é arbitrário tem seu quê de tirânico.

De maneira que se eu traí meu país, sou preso; se matei meu pai, sou preso; todos os delitos imagináveis são punidos da maneira mais uniforme. Tenho a impressão de ver um médico que, para todas as doenças, tem o mesmo remédio. ${ }^{42}$

${ }^{42}$ CHABROUD, Ch. Archives parlementaires, t. XXVI, p. 618. Apud FOUCAULT, Michel. Vigiar e Punir, p. 97. 
A punição ideal é transparente ao crime que sanciona. A arte de punir consiste em encontrar para um crime o Castigo que tão certo e desvantajoso que torne a ideia do delito completamente sem atração. Eis, então, a beleza do jogo de sinais-obstáculos dos reformadores: o Castigo se torna uma consequência lógica do delito, ele se infiltra na mente de qualquer aspirante ao crime e freia suas vontades criminosas antes que elas vejam a luz.

Através da publicidade, também se garantiria o caráter preventivogeral da pena. Como dito antes, haverá um deslocamento na mecânica do exemplo. Não será mais como no suplício ou mesmo como no modelo atual, quando o exemplo é usado para incutir medo físico e pavor coletivo; o exemplo é, agora, a prova de um obstáculo, a exposição da moralidade pública. Isso, pois o exemplo não é mais uma exibição de força do soberano, análoga ao próprio crime, mas sim um restaurador da lei, antinômico ao crime.

Então se poderá inverter na sociedade o tradicional discurso do crime. (...) Em lugar dessas louvações que tornam o criminoso um herói, só se propagarão então no discurso dos homens esses sinais-obstáculos que impedem $o$ desejo do crime pelo receio calculado do castigo. A mecânica positiva funcionará totalmente na linguagem de todos os dias, e esta a fortalecerá sem cessar com novas narrativas. $O$ discurso se tornará o veículo da lei: princípio constante da recodificação universal. ${ }^{43}$

Ao implementar o modelo dos reformadores a prisão não será descartada, será modificada. Será pena específica para alguns crimes, bem como será utilizada para garantir a execução de certas penas. Mas ela jamais será utilizada de forma uniforme, para todos os crimes, e não deve permanecer a mesma. As penitenciárias como conhecemos devem ser inteiramente modificadas, de forma a não cortar ou, ainda, a proteger os laços do presidiário com a comunidade.

\footnotetext{
${ }^{43}$ FOUCAULT, Michel. Vigiar e Punir, p. 93.
} 


\section{A Atividade Terapêutica.}

Dissociar o Castigo e a ressocialização não significa que essa segunda precisa ser descartada. Pelo contrário, ela deve continuar existindo, pois ela é um auxílio essencial aos membros da sociedade que se desviam (ou são desviados) do caminho da lei. A atividade terapêutica precisa, meramente, ser reformulada.

É necessário elaborar um novo instituto para ressocialização. Um instituto que fuja das premissas coercitivas e despersonalizantes da penitenciária. Um instituto que funcione alheio ao Castigo ou, até mesmo, que o substitua. Deve-se entender, principalmente, que a ressocialização de um criminoso só será bem sucedida se contarem com sua boa-vontade e mantiverem seus laços com a sociedade.

Aos zelotes da penitenciária, a ideia parece impossível. Como um criminoso poderia, voluntariamente, se submeter à ressocialização? E os riscos de mantê-lo junto à comunidade?

Primeiramente, cumpre lembrar que, feita a dissociação entre função punitiva e atividade terapêutica, uma nova e mais eficiente forma de Castigo teria sido desenvolvida. Dessa forma, entende-se que os ânimos inquietos da sociedade já teriam sido satisfeitos e que sua "justiça" já teria sido servida, deixando a ressocialização livre para agir de forma pontual e efetiva.

Afinal, uma vez que a ressocialização depende da aderência voluntária de seus pacientes, ela agirá de forma pontual. Como a reabilitação de um viciado em drogas, a regeneração do criminoso depende de sua própria vontade de adotar as práticas terapêuticas e ser regenerado. Somente um criminoso que tenha entendido precisar de ajuda pode passar pela ressocialização. De outra forma, seria domesticação mais uma vez. 
Por mais estranha que pareça essa premissa, ela não é apenas correta como é viável - e a prova disso não está apenas nos centros de reabilitação.

Basta olhar para o próprio Brasil. Nasceram, em 1972, no estado de Minas Gerais, as APACs, a instituição criada pelo advogado Mário Ottoboni para evangelizar e dar apoio aos presidiários ${ }^{44}$. Originalmente, a sigla significava "Amando o Próximo Amarás a Cristo", denunciando o viés eminentemente religioso do projeto, mas, em 1974, sua administração concluiu por sua transformação em entidade jurídica sem fins lucrativos, modificando seu nome para "Associação de Proteção e Assistência aos Condenados". Com o novo objetivo de auxiliar na execução da pena e recuperar os presos, as APACs receberam chancela do Tribunal de Justiça de Minas Gerais e do respectivo governo estadual, em 2001 e 2004, respectivamente, tornando-se aptas a firmar convênios com o governo estadual e recebendo verba pública para construir novas unidades e mantê$\operatorname{las}^{45}$.

Hoje, as APACs se espalham pelos estados do Espírito Santo, Rio Grande do Norte, Maranhão, Mato Grosso, Paraná, Rio Grande do Sul e Minas Gerais, sendo que este último já possui 39 unidades e tem planos de abrir mais $58^{46}$. O método está, inclusive, em processo de exportação para outros 27 países, dentre os quais estão os Estados Unidos, a Alemanha e a Rússia $^{47}$.

Tudo isso em razão de seu incrível "sucesso". Afinal, as APACs apresentam uma taxa de reincidência que varia de $8 \%$ a $12 \%$ (em contraposição aos $70 \%$ da penitenciária comum), de acordo com o

\footnotetext{
${ }^{44}$ FRATERNIDADE BRASILEIRA DE ASSISTÊNCIA AOS CONDENADOS. A APAC: $o$ que $e ́$ ? <http://www.fbac.org.br/index.php/pt/como-fazer/apac-o-que-e> Acesso em: 21/11/2016.

${ }^{45}$ MARTINO, Natália. Índice de reincidência no crime é menor em presos das Apacs. 〈http://www.bbc.com/portuguese/noticias/2014/03/140313_prisoes_apac_nm_lk> Acesso em: $21 / 11 / 2016$

46 TRIBUNAL DE JUSTIÇA DO ESTADO DE MINAS GERAIS. APAC. <http://www.tjmg.jus.br/portal/acoes-e-programas/novos-rumos/apac/> Acesso em: 21/11/2016.

${ }^{47}$ FRATERNIDADE BRASILEIRA DE ASSISTÊNCIA AOS CONDENADOS. Presença do Movimento das APACs em vários países. <http://www.fbac.org.br/index.php/realidadeatual/mapas-2> Acesso em: 21/11/2016.
} 
Conselho Nacional de Justiça ${ }^{48}$ e geram um custo mensal, por preso, de menos de $\mathrm{R} \$ 1.000,00$ (ao invés do máximo de $\mathrm{R} \$ 2.800,00$ do sistema comum), tudo isso sem constar um único assassinato ou rebelião.

Entretanto, é apenas possível falar de sucesso para as APACs colocando-o entre aspas. De fato, elas cumprem com seu objetivo de auxiliar na ressocialização, entretanto seus resultados estão longe de demonstrar serem substitutas eficientes para as penitenciárias. Isso porque o método APAC não enfrenta todos os problemas do sistema penal comum, como a superlotação e as disputas de facções e tampouco lidam com muitos dos problemas de pessoal, pois grande parte sua equipe é voluntária ou são os próprios presos. Tais fatos não invalidam seu método, mas o impossibilitam de ser aplicado em escala nacional e o forçam a permanecer em segundo plano no sistema penal.

Não obstante seus defeitos, há de se parabenizar o método APAC por implantar uma verdadeira atividade terapêutica. Apesar de funcionar em substituição das penitenciárias, as APACs funcionam sob um regime de regras diferente - um que deve ser expressamente aceito, no momento que o juiz designa o preso para o ingresso nela. Dessa forma, a administração pode contar com a cooperação e o engajamento do interno, além de que, ao dar-lhe respeito e confiança, receberá o mesmo em troca. A partir daí, conseguem delegar-lhes trabalhos importantes (por exemplo, o controle das câmeras de segurança ou das celas), confiar-lhes com garfos e facas, não ter guardas armados e garantir-lhes assistência médico-psicológica. Todo esse trabalho contrário à prisionização acaba por colaborar com a possibilidade de instalar as APACs junto às cidades (ao invés de isolá-la), onde não

\footnotetext{
${ }^{48}$ VASCONCELLOS, Jorge. CNJ recomenda a expansão das APACs para a redução da reincidência criminal no país. <http://www.cnj.jus.br/noticias/cnj/61552-cnj-recomendaexpansao-das-apacs-para-a-reducao-da-reincidencia-criminal-no-pais> Acesso em 21/11/2016.
} 
apenas é possível manter os laços familiares e afetivos do interno, como também se garante a ajuda de voluntários ${ }^{49}$.

Inegavelmente, há muito que aprender com as APACs. Elas são, no mínimo, grande fonte de conhecimento empírico daquilo que é necessário para a elaboração de um instituto eficaz de ressocialização. Reformulado o Castigo, as APACs poderiam vir a ser aplicadas de forma subsidiária aos condenados ou mesmo de forma substitutiva, contando que os devidos ajustes sejam feitos na lei e nela própria, para adequá-la ao novo sistema.

\section{O Direito Penal Mínimo e o Abolicionismo Penal.}

A mudança não para por aí. Não basta criar uma nova forma de Castigo e inventar um novo instituto de ressocialização, para que tais novidades se sustentem, é necessário remodelar todo o sistema penal recriá-lo do zero, talvez. Afinal, de pouco adiantariam as mudanças se elas coexistirem com um sistema tão moroso, injusto e punitivo quanto o atual.

Existem, hoje, duas grandes correntes de propostas para um novo sistema penal: o direito penal mínimo e o abolicionismo penal. Ambas são propostas que reconhecem a existência de uma deslegitimação do modelo vigente e a enfrentam, respondendo com modelos alternativos, ao invés de insistir no erro.

$\mathrm{O}$ direito penal mínimo - às vezes chamado de minimalismo penal nega a legitimidade do sistema penal atual e propõe a instauração de um sistema alternativo de mínima intervenção, considerando-a como mal necessário. Nesta corrente, o direito penal fica como o responsável pela substituição da relação bilateral "ofensor-ofendido" pela trilateral "ofensorautoridade-ofendido", colocando a autoridade judicial nessa terceira e

\footnotetext{
49 GAMA, Jessica. A lei de execução penal a luz do Método APAC. $<$ http://drajessicagama.jusbrasil.com.br/artigos/229836759/a-lei-de-execucao-penal-a-luz-dometodo-apac> Acesso em: 21/11/2016.
} 
imparcial posição. Seu fundamento existencial é, essencialmente, impeditivo de vingança, pois argumenta que, sem a intervenção do direito penal, não há nada para minimizar a reação violenta da sociedade contra o delito.

Simultaneamente, entende-se que se deve restringir a intervenção penal ao mínimo. Através de uma redução radical das penas de prisão e uma considerável descriminalização, os defensores dessa proposta pretendem reduzir os efeitos negativos da prisionização, da morosidade do judiciário e da qualidade do Castigo. As causas que forem demovidas do nível de crime, isto é, os delitos que não são, verdadeiramente, danosos à sociedade, são deixados para a esfera cível. Lá, o ofendido pode satisfazer seu direito lesado sem necessidade de movimentação da máquina criminal, que ficará reservada para as causas que precisam de um cuidado especial em sua resolução.

O direito penal mínimo é, sem dúvidas, a alternativa abraçada por este trabalho. Afinal, ele propõe uma reformulação do sistema penal por meio da redução (ou até remoção) das penitenciárias de sua regra geral, enquanto ainda mantém o Castigo para os crimes mais sensíveis à sociedade - justamente porque entende que a necessidade de conter os ânimos da população com o histórico instituto.

O abolicionismo penal pode, por sua vez, ser considerado um pouco mais radical. Ele se assemelha à corrente minimalista ao reconhecer as falhas o sistema penal vigente, porém sua diferença surge ao afirmar que qualquer outro sistema penal - presente ou futuro - seria igualmente deslegitimado. O abolicionismo prega, assim, pela radical substituição do sistema penal por outras formas de resolução de conflitos.

Louk Hulsman, considerado o pai do abolicionismo, defende que deve-se instalar uma nova linguagem na dinâmica da resolução de conflitos. Em sua proposta, não mais se falará de "crimes" e "criminosos", mas sim 
de "situações problemáticas". Essa mera redefinição é o suficiente para dar outro ponto de vista à situação e chegar ao coração do conflito, onde se pode resolvê-lo atendendo às necessidades reais dos envolvidos. No final de contas, o modelo sugere que a resolução de conflitos se dê de forma mais pessoal e comunitária, na via cível (com soluções compensatórias, terapêuticas, educativas e etc).

Tais propostas são, no mínimo, controversas. Abdicar do sistema penal como um todo, da forma que Hulsman coloca, é mais do que o Estado deixar de aplicar o Castigo, é impedir que a sociedade também o aplique - o que não é uma tarefa exatamente simples. Como já colocado, a sociedade exige o Castigo e lutará para ver sua "justiça" servida, de forma que o abolicionismo jamais alcançaria a perfeição que pleiteia. Invariavelmente, o que seu modelo conseguiria seria ou uma anarquia punitiva - na qual o povo aplicaria o Castigo com suas próprias mãos, rebelando-se contra o Estado - ou um rígido disciplinarismo social - no qual o Estado imporia uma disciplina tão estrita e um policiamento tão forte que a sociedade não teria escolha que não suprimir seus anseios de "justiça" e os converter no mais puro ressentimento.

A defesa contra essas críticas, conforme colocada por Eugenio Raúl Zaffaroni $^{50}$, é que o abolicionismo propõe, junto da abdicação do Castigo, a adoção de um novo modelo de sociedade. Ele ainda ressalva:

$\mathrm{Na}$ verdade, o abolicionismo não pretende renunciar à solução dos conflitos que devem ser resolvidos; apenas, quase todos os seus autores parecem propor uma reconstrução de vínculos solidários de simpatia horizontais ou comunitários, que permitam a solução desses conflitos sem a necessidade de apelar para o modelo punitivo formalizado abstratamente. ${ }^{51}$

A ideia é, no mínimo, ingênua. Afinal, ela pressupõe o auxílio e a boa-fé de uma sociedade que frequentemente prefere amarrar criminosos a postes e/ou linchá-los antes de submetê-los ao devido processo legal. Ela confia que terá a solidariedade e o apoio comunitário de todo um povo,

\footnotetext{
${ }^{50}$ ZAFFARONI, Eugenio Raúl. Em busca das penas perdidas, p. 104.

${ }^{51}$ Ibid. p. 104.
} 
desconsiderando que esse povo nunca esteve tão desconectado um do outro $^{52}$ e que a incidência de doenças mentais como depressão e distúrbios de ansiedade também nunca foi tão alta ${ }^{53}$.

Aplicar a proposta abolicionista seria trocar uma ilusão pela outra. Jamais seu modelo de sociedade funcionaria se implantado em direta sucessão do modelo atual. A mudança seria muito brusca para que os vingativos indivíduos contemporâneos pudessem se adaptar.

É por isso que a proposta do direito penal mínimo é tão interessante. Além de ser inteiramente fazível em curto espaço de tempo, sua nova sociedade poderia servir como intermediário para a futura aplicação do abolicionismo - uma vez que suas propostas seriam, na pior das hipóteses, menos distantes.

Ou, como o próprio Zaffaroni colocou:

Em nossa opinião, o direito penal mínimo é, de maneira inquestionável, uma proposta a ser apoiada por todos os que deslegitimam o sistema penal, não como meta insuperável e, sim, como passagem ou trânsito para o abolicionismo, por mais inalcançável que este hoje pareça; ou seja, como um momento do "unfinished" de Mathiesen e não como um objetivo "fechado" ou "aberto". 54

Somem, portanto, as dúvidas. O direito penal mínimo emerge como a mais viável - senão a única - das correntes que respondem à deslegitimação do sistema penal, pois seu modelo reconhece o Castigo como uma necessidade da sociedade, ao invés de a raiz de todos os problemas. Talvez, com o tempo, tal necessidade venha a desaparecer, mas por enquanto essa é uma vil verdade com a qual se tem de conviver. Afinal, o direito penal é, infelizmente, "uma amarga necessidade de seres imperfeitos" 55.

\footnotetext{
52 DAY, Elizabeth. The new fast ways of keeping in touch are driving us further apart. $<\mathrm{https} / / / \mathrm{www}$.theguardian.com/technology/2009/nov/01/email-facebook> Acesso em: 21/11/2016. ${ }^{53}$ MONBIOT, George. Neoliberalism is creating loneliness. That's what's wrenching society apart. <https://www.theguardian.com/commentisfree/2016/oct/12/neoliberalism-creatingloneliness-wrenching-society-apart> Acesso em: 21/11/2016.

${ }^{54}$ ZAFFARONI, Eugenio Raúl. Em busca das penas perdidas, p. 106.

${ }^{55}$ Conforme afirmou o Projeto de Código Penal Alemão de 1966.
} 


\section{Conclusão}

O presente trabalho se esforçou para demonstrar que o Castigo é fundamental à ressocialização dos condenados e que o verdadeiro impeditivo da ressocialização é a forma com que ela é "feita", hoje.

As penitenciárias não são um espaço de ressocialização, diferentemente do que pleiteia a lei penal. Lá, aqueles que seriam responsáveis pela regeneração dos detentos se importam apenas em lhes incutir uma fria disciplina e domesticá-los sob os golpes de um porrete, a fim de preservar seus próprios empregos. $\mathrm{Na}$ ausência de atividade terapêutica, resta apenas a função punitiva, mas essa é apenas uma forma subvertida do Castigo, incapaz de reparar os egos feridos da sociedade, mas capaz de corromper aqueles que deveria regenerar.

Os malefícios de um Castigo mal executado podem nublar a visão dos teóricos, impedindo-lhes de enxergar que, na verdade, ele é essencial à ordem social. O sofrimento alheio sempre foi festejado pela sociedade e, por cumprir uma função de "reparação", o Castigo sempre fora usado quando o povo se sentia lesado. Removê-lo é, para aquele que é lesado, manter a uma ferida aberta, enquanto executá-lo de forma excessiva é, simplesmente, tirania.

O Castigo traz a paz a um povo que se sente em guerra - a ressocialização tem pouco a ver com isso. Os dois só se misturam, pois o sistema penal vigente escolheu misturá-los; e, por isso, é impossível executar os dois com perfeição.

É necessário elaborar algo novo, um novo sistema penal. Precisa-se parar de insistir nos erros da penitenciária, parar de misturar a função punitiva com a atividade terapêutica. Criar novos institutos e reformar o que temos. Um novo Castigo, uma nova ressocialização; e, sob a bandeira de um direito penal mínimo, fundar um novo sistema penal. 


\section{Bibliografia}

THOMPSON, Augusto. A Questão Penitenciária. 5 $5^{\mathrm{a}}$ Edição. Rio de Janeiro: Editora Forense, 2000.

FOUCAULT, Michel. Vigiar e Punir: Nascimento da Prisão. 33a Edição. Petrópolis: Editora Vozes, 2007. 288p.

BECCARIA, Cesare. Dos Delitos e das Penas. 2a Edição. São Paulo: Editora Edipro, 2015.

NIETZSCHE, Friedrich. Genealogia da Moral: Uma polêmica. São Paulo: Companhia de Bolso, 2009.

ZAFFARONI, Eugenio Raúl. Em busca das Penas Perdidas: a perda da legitimidade do sistema penal. $5^{\text {a }}$ Edição. Rio de Janeiro: Editora Revan, 2001.

CROSS, Rupert. Punishment prison and the public. $2^{\mathrm{a}}$ Edição. Londres: Stevens and Sons, 1971. p. 47. Apud THOMPSON, Augusto. A Questão Penitenciária. 5a Edição. Rio de Janeiro: Editora Forense, 2000. p. 5.

KNUDTEN, Richard D.. Crime in a Complex Society. Illinois: Dorsey Press, 1970. p. 612. Apud THOMPSON, Augusto. A Questão Penitenciária.

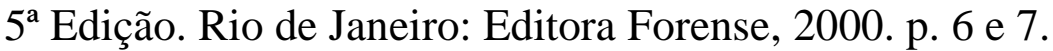

CLEMMER, Donald. "Prisionization" em: JOHNSTON, SAVITZ E WOLFGANG. The Sociology of Punishment \& Correction. 2 $2^{\mathrm{a}}$ Edição. Nova Iorque: Jon Wiley and Sons, 1970. p. 579-483. Apud THOMPSON, Augusto. A Questão Penitenciária. 5a Edição. Rio de Janeiro: Editora Forense, 2000. p. 23.

CHARRIÈRE, Henri. Papillon. Paris: Ed. Robert Laffont, 1969. p. 509 Apud THOMPSON, Augusto. A Questão Penitenciária. $5^{\mathrm{a}}$ Edição. Rio de Janeiro: Editora Forense, 2000. p. 13. 
DUPORT, A. Archives parlamentaires. Paris: Discurso na Constituinte, 1789. t. X, p. 744. Apud FOUCAULT, Michel. Vigiar e Punir. p. 77.

CHABROUD, Ch. Archives parlementaires, t. XXVI, p. 618. Apud FOUCAULT, Michel. Vigiar e Punir, p. 97.

O GLOBO. Suécia fecha quatro presídios por falta de condenados. Disponível em: <http://oglobo.globo.com/mundo/suecia-fecha-quatropresidios-por-falta-de-condenados-10769563> Acesso em: 21/11/2016.

BOCCHINI, Lino. Suécia fecha 4 prisões e prova: a questão é social. Disponível em: <http://www.cartacapital.com.br/sociedade/suecia-fecha-4prisoes-e-prova-mais-uma-vez-a-questao-e-social-334.html> Acesso em: 21/11/2016.

SCOLESE, Eduardo. Presos filmam decapitados em penitenciárias no Maranhão; veja vídeo. Disponível em: <http://www1.folha.uol.com.br/cotidiano/2014/01/1394160-presos-filmamdecapitados-em-penitenciaria-no-maranhao-veja-video.shtml> Acesso em: 21/11/2016.

BORGES, Bruna; CALGARO, Fernanda. A única coisa boa do Maranhão é o presídio de Pedrinhas, diz Bolsonaro. Disponível em: $<$ http://noticias.uol.com.br/politica/ultimas-noticias/2014/02/11/minhaproposta-e-defender-direitos-da-maioria-e-nao-da-minoria-dizbolsonaro.htm> Acesso em: 21/11/2016.

FRATERNIDADE BRASILEIRA DE ASSISTÊNCIA AOS CONDENADOS. A APAC: o que é? Disponível em: $<$ http://www.fbac.org.br/index.php/pt/como-fazer/apac-o-que-e> Acesso em: 21/11/2016.

MARTINO, Natália. Índice de reincidência no crime é menor em presos das Apacs. Disponível em: 
<http://www.bbc.com/portuguese/noticias/2014/03/140313_prisoes_apac_n m_lk> Acesso em: 21/11/2016.

TRIBUNAL DE JUSTIÇA DO ESTADO DE MINAS GERAIS. APAC. <http://www.tjmg.jus.br/portal/acoes-e-programas/novos-rumos/apac/> Acesso em: 21/11/2016.

FRATERNIDADE BRASILEIRA DE ASSISTÊNCIA AOS CONDENADOS. Presença do Movimento das APACs em vários países. Disponível em: <http://www.fbac.org.br/index.php/realidade-atual/mapas2> Acesso em: 21/11/2016.

VASCONCELLOS, Jorge. CNJ recomenda a expansão das APACs para a redução da reincidência criminal no país. Disponível em: <http://www.cnj.jus.br/noticias/cnj/61552-cnj-recomenda-expansao-dasapacs-para-a-reducao-da-reincidencia-criminal-no-pais> Acesso em $21 / 11 / 2016$.

GAMA, Jessica. A lei de execução penal a luz do Método APAC. Disponível em: <http://drajessicagama.jusbrasil.com.br/artigos/229836759/a-lei-deexecucao-penal-a-luz-do-metodo-apac> Acesso em: 21/11/2016.

DAY, Elizabeth. The new fast ways of keeping in touch are driving us further apart. Disponível em: <https://www.theguardian.com/technology/2009/nov/01/email-facebook> Acesso em: 21/11/2016.

MONBIOT, George. Neoliberalism is creating loneliness. That's what's wrenching society apart. Disponível em: <https://www.theguardian.com/commentisfree/2016/oct/12/neoliberalismcreating-loneliness-wrenching-society-apart> Acesso em: 21/11/2016. 